\title{
Assessment of factors related to smokers' adherence to a short-term support group for smoking cessation: a longitudinal study in a developing country
}

\author{
Avaliação dos fatores associados à adesão de fumantes a um grupo de apoio \\ de curta duração para a cessação de tabagismo: um estudo longitudinal em \\ um país em desenvolvimento
}

Luciana Rizzieri Figueiró, Helena Maria Tannhauser Barros, Maristela Ferigolo, Denise Conceição Mesquita Dantas*

\begin{abstract}
Objective: The aim of this study was to determine which individual characteristics of smokers are associated with their adherence to a support group for smoking cessation.

Methods: Smokers from Porto Alegre, Brazil, were invited to participate in a support group for smoking cessation consisting of four weekly sessions. Demographic data, smoking history, presence of tobacco-related diseases, severity of nicotine dependence, stage of motivation, and symptoms of anxiety and depression were evaluated at baseline. Adherence was defined as attendance at group sessions and was measured the second and fourth sessions of the program.

Results: The study recruited 167 smokers who attended the first meeting and met criteria for admission to the study. One hundred and two of the participants returned to the second session and only 55 of those who attended the first meeting completed the four-week program. For immediate adherence (second session), adult smokers over the age of 35 were more likely to adhere to the treatment $(p=0.004)$, whereas smoking higher numbers of cigarettes per day was associated with lower adherence to attendance at group meetings $(p=0.031)$. For final adherence (fourth session), only minimal level symptoms of anxiety were associated with a higher likelihood of adherence $(p=0.02)$.

Conclusions: Older smokers, those who smoked fewer cigarettes per day, and those with lower levels of anxiety exhibited higher rates of adherence to a smoking cessation support group. Keywords: Adherence, smoking cessation, motivation, tobacco use disorder, comorbidity.
\end{abstract}

\section{Resumo}

Objetivo: $\mathrm{O}$ objetivo deste estudo foi determinar quais características individuais de fumantes estão associadas à sua adesão a um grupo de apoio para a cessação do tabagismo.

Métodos: Fumantes de Porto Alegre, Brasil, foram convidados a participar de um grupo de apoio para a cessação do tabagismo realizado em quatro reuniões semanais. Dados sociodemográficos, história tabagística, presença de doenças relacionadas ao tabaco, severidade da dependência de nicotina, estágio motivacional e sintomas de ansiedade e depressão foram avaliados no início do estudo. Adesão foi definida como estar presente nas reuniões do grupo, e foi medida na segunda e na quarta sessões do programa.

Resultados: O estudo recrutou 167 fumantes que compareceram ao primeiro encontro e preencheram os critérios de inclusão. Desses participantes, 102 retornaram para a segunda sessão, e apenas 55 completaram as quatro semanas do programa. Com relação à adesão imediata (segunda sessão), adultos com idade superior a 35 anos mostraram maior probabilidade de aderir ao tratamento ( $p=0.004)$, enquanto um maior número de cigarros por dia foi associado com menor adesão $(p=0.031)$. Para a adesão final (quarta sessão), apenas um nível mínimo de ansiedade foi associado com maior probabilidade de adesão $(p=0.02)$. Conclusões: Fumantes mais velhos, que fumavam menos cigarros por dia, e com menores níveis de ansiedade exibiram maiores taxas de adesão ao programa de apoio para a cessação do tabagismo.

Descritores: Adesão, cessação do tabagismo, motivação, transtorno por uso de tabaco, comorbidade.

* Universidade Federal de Ciências da Saúde de Porto Alegre (UFCSPA), Porto Alegre, RS, Brazil.

Financial support: Secretaria Nacional de Políticas sobre Drogas (SENAD) and Associação Mário Tannhauser de Ensino, Pesquisa e Assistência (AMTEPA). Helena Maria Tannhauser Barros receives a 1C Research Productivity Grant from Conselho Nacional de Desenvolvimento Científico e Tecnológico (CNPq).

Submitted Jun 08 2016, accepted for publication Oct 12 2016. No conflicts of interest declared concerning the publication of this article.

Suggested citation: Figueiró LR, Barros HMT, Ferigolo M, Dantas DCM. Assessment of factors related to smokers' adherence to a short-term support group for smoking cessation: a cross sectional study in a developing country. Trends Psychiatry Psychother. 2017;39(1):19-28. http://dx.doi.org/10.1590/2237-60892016-0041 


\section{Introduction}

There are nearly 22 million smokers in Brazil and $15 \%$ of the population aged 15 years or over smokes. Almost $44 \%$ of male current smokers and $53 \%$ of female current smokers have tried to quit smoking in the past 12 months, ${ }^{1}$ but only $15.2 \%$ and $6.7 \%$ did so, with the help of counseling or pharmacotherapy respectively. ${ }^{2}$ Cognitivebehavioral therapy plus medication is the treatment method for smoking cessation. However, pharmacotherapy is overvalued and there is minimal emphasis on unassisted cessation or behavioral treatment. ${ }^{3}$ Since pharmacotherapy is prohibitively expensive for low-income populations, it is of interest to be able to predict which smokers would continue attending behavioral treatment alone, in order to initially invest in this approach with those individuals. Moreover, group behavior programs for smoking cessation may be economically more attractive because smokers can be given more counseling time and more people can be treated by a single professional simultaneously. ${ }^{4}$ This is particularly important in Brazil, since the available resources are insufficient to provide care for all those who need it, despite increasing efforts to provide smokers with treatment. 2,5 To effectively assist larger numbers of smokers with a group approach would lead to a reduction in costs for public health administrations, allowing application of financial resources to purchase more medications for those smokers who really need them to quit.

However, even in trials in which smokers have agreed to attend treatment meetings, the non-participation rate is often high. Adherence is patient acceptance of recommended health behaviors, such as taking medication, adopting a proposed diet, or changing lifestyle habits ${ }^{6}$ and proves a challenge for health professionals. Generally, higher levels of adherence to medical treatment are associated with better health outcomes and with public health cost reductions. ${ }^{7-10}$ However, it is difficult to compare findings on adherence, because the term can have different meanings; ranging from merely participating (sometimes termed retention), to actually following the proposed regimen until the desired outcome is achieved. ${ }^{11}$ Higher adherence to smoking treatment is associated with a higher chance of nicotine abstinence and higher latency to relapse. ${ }^{12,13}$

Average rates of adherence to multiple sessions of behavioral smoking cessation treatments range from 30 to $66 \% .^{14-19}$ In Brazil, the rate of adherence to group intervention for smoking cessation varies from 67 to $95 \% .^{20-23}$ These high rates do not seem to represent clinical practice.

Some studies show that adherence to smoking treatment may be associated with personal characteristics including the pattern of tobacco use ${ }^{24}$ and depression and anxiety symptoms experienced during withdrawal. ${ }^{14,25-27}$ In general, depression and anxiety are risk factors for poor adherence to recommended preventative behaviors, ${ }^{28}$ including quitting smoking. Furthermore, few studies have specifically examined factors predictive of dropout from smoking cessation programs. In general, studies have long observation periods, but it is important to identify early which smokers are more likely to remain engaged in treatment. We consider that it is important to understand the personal characteristics that favor or negatively impact on adherence to smoking cessation treatment, because this insight should help with development of practices that can promote engagement and, consequently, improve support group effectiveness. The objective of this study was therefore to determine whether people who were adherent to a smoking cessation support group, i.e. those who attended the meetings, had different characteristics to those who were non-adherent, in terms of demographic variables, smoking history, presence of tobacco-related diseases, severity of nicotine dependence, motivation stage, and symptoms of anxiety and depression.

\section{Methods}

\section{Participants}

The study participants were male and female smokers aged 18 or over and living in Porto Alegre, Brazil. Smokers were recruited from the community by newspaper and radio advertisements publicizing a support group for smoking cessation. People who were interested called a call-center for drug abuse prevention and were given a description of how the group sessions would be conducted and participation in a group was then scheduled if the smoker chose to participate. The people enrolled were current cigarette smokers who presented on the date scheduled. Smokers under 18 years of age or those who reported current illicit drugs use, nicotine replacement therapy, bupropion treatment, or the presence of debilitating conditions that could interfere with group participation were excluded.

Table 1 contains the characteristics of the 166 smokers who participated in the study.

\section{Procedures}

Smokers participated in a free of charge program for smoking cessation between July 2007 and November 2009. The program consisted of four weekly group meetings with 8 to 12 participants, which were conducted by health professionals trained in cognitive-behavioral and 
Motivational Interviewing techniques. ${ }^{29}$ Each session lasted about two hours and was structured according to American Cancer Society and Brazilian National Cancer Institute recommendations. ${ }^{30,31}$

Table 1 - Sociodemographic characteristics, smoking history, presence of tobacco-related illnesses, smoking intensity, motivational stage, and symptoms of anxiety and depression among smokers in a short-term support group for smoking cessation $(n=166)$

\begin{tabular}{|c|c|}
\hline & n (\%) \\
\hline \multicolumn{2}{|l|}{ Sociodemographic data } \\
\hline \multicolumn{2}{|l|}{ Gender $(n=166)$} \\
\hline Female & $108(65.1)$ \\
\hline \multicolumn{2}{|l|}{ Age $(n=164)$} \\
\hline Mean \pm SD & $49.5 \pm 11.3$ \\
\hline \multicolumn{2}{|l|}{ Marital status $(n=166)$} \\
\hline Married & $82(49.4)$ \\
\hline Single, divorced, widowed & $84(50.6)$ \\
\hline \multicolumn{2}{|l|}{ Education $(n=163)$} \\
\hline$\leq 8$ years & $42(25.9)$ \\
\hline $8-11$ years & $65(40.2)$ \\
\hline > 11 years & 55 (33.9) \\
\hline \multicolumn{2}{|l|}{ Occupation $(n=149)$} \\
\hline Unpaid & $18(12.1)$ \\
\hline Paid & $131(87.9)$ \\
\hline \multicolumn{2}{|l|}{ Household income $(n=131)$} \\
\hline$\leq$ US\$1330/month & $76(58.0)$ \\
\hline > US\$ $1330 /$ month & $55(42.0)$ \\
\hline \multicolumn{2}{|l|}{ General characteristics } \\
\hline \multicolumn{2}{|l|}{ Tobacco-related disease $(n=166)$} \\
\hline Yes & $117(70.5)$ \\
\hline \multicolumn{2}{|l|}{ Medical treatment $(n=165)$} \\
\hline Yes & $44(26.7)$ \\
\hline \multicolumn{2}{|l|}{ Drinking $(n=163)$} \\
\hline Yes & $69(42.3)$ \\
\hline \multicolumn{2}{|l|}{ Tobacco consumption } \\
\hline \multicolumn{2}{|l|}{ Age started smoking $(n=166)$} \\
\hline Childhood/adolescence $(<19$ years) & $133(80.1)$ \\
\hline Adulthood ( $\geq 19$ years) & $33(19.9)$ \\
\hline \multicolumn{2}{|l|}{ Daily cigarette consumption $(n=166)$} \\
\hline$\leq 20$ & $109(65.7)$ \\
\hline$>20$ & $57(34.3)$ \\
\hline \multicolumn{2}{|l|}{ Previous attempt to quit $(n=163)$} \\
\hline Yes & $130(79.8)$ \\
\hline \multicolumn{2}{|l|}{ Tobacco dependence - NHSDA $(n=129)$} \\
\hline Yes & $112(86.8)$ \\
\hline \multicolumn{2}{|l|}{ FTND $(n=165)$} \\
\hline$\geq 5$ (moderate to very heavy) & $101(61.2)$ \\
\hline$<5$ (very light to light) & $64(38.8)$ \\
\hline \multicolumn{2}{|l|}{ Motivation } \\
\hline \multicolumn{2}{|l|}{ Contemplation ladder $(n=164)$} \\
\hline Precontemplation/contemplation & $29(17.7)$ \\
\hline Preparation/action & $135(82.3)$ \\
\hline \multicolumn{2}{|l|}{ URICA $(n=164)$} \\
\hline Low motivation & $143(87.2)$ \\
\hline High motivation & $21(12.8)$ \\
\hline \multicolumn{2}{|l|}{ Comorbidities } \\
\hline $\begin{array}{l}\text { Symptoms of depression - BDI }(n= \\
159)\end{array}$ & \\
\hline Mild/moderate/severe (>11) & $82(51.6)$ \\
\hline Minimal $(\leq 11)$ & $77(48.4)$ \\
\hline Symptoms of anxiety - BAI $(n=162)$ & \\
\hline Mild/moderate/severe $(>10)$ & $87(53.7)$ \\
\hline Minimal $(\leq 10)$ & $75(46.3)$ \\
\hline
\end{tabular}

$\mathrm{BAI}=$ Beck Anxiety Inventory; BDI = Beck Depression Inventory; FTND = Fagerström Test for Nicotine Dependence; NHSDA = National Household Survey on Drug Abuse; SD = standard deviation; URICA = University of Survey on Drug Abuse; SD = standard devi
Rhode Island Change Assessment Scale.
Participants were informed about the study objectives and procedures at the beginning of the first session and informed consent was obtained from all participants. The smokers answered a self-administered questionnaire covering sociodemographic characteristics, their perceived health status, smoking history, nicotine dependence, symptoms of anxiety and depression, and stage of motivation. The second session was devoted to planning the attempt to quit. Information was provided about withdrawal signs and symptoms, risk situations, coping strategies, and relaxation exercises, and the quit date was set. In the third session, difficulties experienced while trying to quit were discussed and strategies for remaining abstinent were reinforced. The fourth session was reserved for feedback on strategies for relapse prevention and for reinforcement of skills and learning for those who had not achieved abstinence. After this initial program, monthly follow-up sessions were scheduled and phone counseling was offered.

The study was approved by the Ethics Committee at the Universidade Federal de Ciências da Saúde de Porto Alegre (no. 219/07).

\section{Sampling}

Sampling was by convenience in this study. The sample size was calculated, based on an adherence rate of $55 \%$, observed during the first month of a group intervention for smoking cessation, ${ }^{17}$ to find a relative difference between actual and estimated the proportion of no more than $15 \%$, at $a=0.05$. After addition of $20 \%$ to allow for losses, the sample size calculated corresponded to 162 people.

\section{Study design}

Longitudinal study in two periods (second and fourth session).

\section{Measures}

\section{Sociodemographic characteristics}

The questionnaire included questions on gender, age, marital status, occupation, family income, education level, reported tobacco-related diseases (diabetes, hypertension, cancer, and respiratory and cardiovascular diseases) and use of medication, alcohol, or illicit drugs.

\section{Smoking history}

Smoking history was evaluated using a questionnaire covering the age at which respondents started smoking, number of cigarettes smoked per day, years smoking, 
number of previous attempts to quit smoking, and the longest previous period of abstinence from smoking. ${ }^{32}$

\section{Nicotine dependence}

Dependence was diagnosed on the basis of assessment with the Brazilian National Household Survey on Drug Abuse, a measure which is based on the National Household Survey on Drug Abuse (NHSDA). ${ }^{33,34}$ This questionnaire covers six symptoms of the dependence syndrome: tolerance, lack of control over use, significant time spent in activities related to use, continued use of the substance despite the physical risks and personal problems resulting from use, and at least one unsuccessful attempt to stop or to decrease use. Smokers were considered dependent if they endorsed at least two of these criteria. ${ }^{33}$ Intensity of nicotine dependence was measured using the Fagerström Test for Nicotine Dependence (FTND), a measure which consists of six questions related to smoking. ${ }^{35,36}$ This questionnaire classifies the level of dependence from very low to very high. The total score is calculated by adding the scores obtained for each question, which range from 0 to 10 points.

\section{Motivational stage}

Motivational stage was measured using the University of Rhode Island Change Assessment Scale (URICA) and the Contemplation Ladder. ${ }^{37-39}$ The URICA assesses to what degree participants are willing to change their smoking behavior by indicating whether they agree or disagree with certain statements. Responses are distributed along a Likert scale. Based on the answers, the scores can be equated to stages of precontemplation, contemplation, action, and maintenance, ${ }^{40}$ and a total score can be calculated by adding the averages for the subscales of contemplation, action, and maintenance, and subtracting the mean for the precontemplation subscale. Motivation was defined as high when the total score was above $70 \%$ of the maximum possible score. On the Contemplation Ladder, used in modified form, participants chose one statement from a group of five that best represented their thinking in relation to smoking at the time. The stage of readiness was classified as precontemplation, contemplation, preparation or action.

\section{Symptoms of anxiety}

The Beck Anxiety Inventory (BAI), a measure consisting of 21 items that describe various symptoms of anxiety, was used to assess the levels of symptoms of anxiety. Subjects mark the level of intensity at which they experience each symptom within a range of 0 to 3. The final score is obtained by summing all the items and matching that sum to a standardized severity level: minimal ( 0 to 11 points), mild (12 to 19 ), moderate (20 to 35 ), or severe (36 to 63 ). ${ }^{41,42}$

\section{Symptoms of depression}

Symptoms of depression were assessed using the Beck Depression Inventory (BDI), a measure which consists of 21 items with four response choices ranging from 0 to 3 for each item, corresponding to increasing degrees of intensity of depression. The total score is the result of the sum of the scores of the individual items, and this sum is used to classify levels of depression as minimal ( 0 to 10 points), mild (11 to 19 ), moderate (20 to 30 ), or severe (31 to 63 ). ${ }^{42,43}$

\section{Adherence}

A smoker was considered adherent when he/ she was present at the second session (immediate adherence) or at all four sessions of the support group (final adherence), regardless of whether they had quit smoking or had made any changes in their behavior. This period of four weeks was chosen for analysis because a shorter treatment program may attract more smokers. Moreover, this initial period represents a moment of great importance in the process of smoking cessation, since it has been shown that smokers are most likely to relapse in the first weeks of treatment. ${ }^{44}$

\section{Data analyses}

Statistical analysis was performed to determine whether sociodemographic characteristics, smoking history, knowledge of smoking-related diseases, motivational stage, and symptoms of depression and anxiety were associated with adherence to a program for smoking cessation. Associations between variables and outcomes were identified using the chi-square test. Odds ratios and 95\% confidence intervals were also used. Missing data were excluded analysis by analysis. Variables which yielded significance or exhibited trends in associations $(p<0.2)$ were entered into a multivariate model to control for possible confounding variables. Tests were performed using PASW Statistics 18. Associations were considered significant for $\mathrm{p}<0.05$.

\section{Results}

In total, 183 smokers attended the first meeting. Seventeen smokers were excluded from the study on the basis of inclusion and exclusion criteria. Only 102 (61\%) smokers returned for the second session and 55 (33\%) completed the four-week program (Figure 1). 
Few associations were found between the above variables and smokers' adherence to the program (Table 2). For immediate adherence, adult smokers over the age of 35 were more likely than younger smokers to adhere to treatment $(p=0.017)$. Gender, medical treatment for clinical conditions, and daily cigarette consumption yielded a trend towards associations ( $p$ $<0.2$ ), and therefore these predictors were included in a multivariate logistic regression analysis. Logistic regression analysis confirmed the association between age and immediate adherence $(p=0.004)$ and also indicated that smokers with consumption higher than 20 cigarettes a day dropped out more frequently in the initial group meetings $(p=0.031)$. There was a trend towards association between male sex and nonadherence at this time $(p=0.076)$.

Table 2 - Associations between non-adherence of smokers to group treatment for smoking cessation and sociodemographic characteristics, smoking history, presence of tobacco-related illnesses, smoking intensity, motivational stage, and symptoms of anxiety and depression $(n=166)$

\begin{tabular}{|c|c|c|c|c|c|c|c|c|}
\hline & \multicolumn{4}{|c|}{ Immediate adherence } & \multicolumn{4}{|c|}{ Final adherence } \\
\hline & $\begin{array}{c}\text { Non- } \\
\text { adherents } \\
(n=65) \\
n(\%)\end{array}$ & $x^{2}$ & $\begin{array}{c}\text { OR } \\
\text { (95\%CI) } \\
\text { unadjusted }\end{array}$ & $\begin{array}{c}\text { OR }(95 \% \mathrm{CI}) \\
\text { adjusted }\end{array}$ & $\begin{array}{c}\text { Non- } \\
\text { adherents } \\
(n=112) \\
n(\%)\end{array}$ & $x^{2}$ & $\begin{array}{l}\text { OR }(95 \% \mathrm{CI}) \\
\text { unadjusted }\end{array}$ & $\begin{array}{c}\text { OR } \\
\text { (95\%CI) } \\
\text { adjusted }\end{array}$ \\
\hline \multicolumn{9}{|l|}{ Gender } \\
\hline Male & $28(48.3)$ & 3.56 & $\begin{array}{c}1.82 \\
(0.95-3.48)\end{array}$ & $\begin{array}{c}1.89 \\
(0.95-3.76)\end{array}$ & $40(69.0)$ & 0.18 & $\begin{array}{c}1.16 \\
(0.59-2.29)\end{array}$ & \\
\hline Female & $36(33.3)$ & & 1.0 & 1.0 & $71(65.7)$ & & 1.0 & \\
\hline \multicolumn{9}{|l|}{ Age (2 missing) } \\
\hline$<35$ years & $13(61.9)$ & 5.62 & $\begin{array}{c}3.02 \\
(1.17-7.78)^{*}\end{array}$ & $\begin{array}{c}3.85 \\
(1.43-10.41)^{*}\end{array}$ & $20(95.5)$ & 8.65 & $\begin{array}{c}11.78 \\
(1.54-90.29)^{*}\end{array}$ & $\begin{array}{c}7.71 \\
(0.88-67.79)\end{array}$ \\
\hline$\geq 35$ years & $50(35.0)$ & & 1.0 & 1.0 & $90(62.9)$ & & 1.0 & 1.0 \\
\hline \multicolumn{9}{|l|}{ Marital status } \\
\hline Married & $31(37.8)$ & 0.04 & $\begin{array}{c}0.94 \\
(0.50-1.76)\end{array}$ & & $52(63.4)$ & 0.87 & $\begin{array}{c}0.73 \\
(0.38-1.41)\end{array}$ & \\
\hline Single, divorced, widowed & $33(39.3)$ & & 1.0 & & $59(70.2)$ & & 1.0 & \\
\hline \multicolumn{9}{|l|}{ Education (4 missing) } \\
\hline$\leq 8$ years & $16(40.5)$ & 0.05 & $\begin{array}{c}0.92 \\
(0.45-1.90)\end{array}$ & & $27(64.3)$ & 0.47 & $\begin{array}{c}0.77 \\
(0.37-1.62)\end{array}$ & \\
\hline$>8$ years & $48(38.1)$ & & 1.0 & & $84(70.0)$ & & 1.0 & \\
\hline \multicolumn{9}{|l|}{ Occupation (17 missing) } \\
\hline Unpaid & $7(38.9)$ & 0.0 & $\begin{array}{c}1.03 \\
(0.38-2.83)\end{array}$ & & $13(72.2)$ & 0.13 & $\begin{array}{c}1.23 \\
(0.41-3.67)\end{array}$ & \\
\hline Paid & $50(38.2)$ & & 1.0 & & $89(67.9)$ & & 1.0 & \\
\hline \multicolumn{9}{|c|}{ Household income (35 missing) } \\
\hline$\leq$ US\$1330/month & $37(48.7)$ & 0.33 & $\begin{array}{c}1.23 \\
(0.61- \\
2.46)\end{array}$ & & $59(77.6)$ & 2.37 & $\begin{array}{c}1.83 \\
(0.84-3.97)\end{array}$ & $\begin{array}{l}1.65 \\
(0.67- \\
4.01)\end{array}$ \\
\hline$>$ US\$ $1330 /$ month & $24(43.6)$ & & 1.0 & & $36(65.5)$ & & 1.0 & 1.0 \\
\hline \multicolumn{9}{|l|}{ Tobacco-related disease } \\
\hline Yes & $48(41.0)$ & 1.02 & $\begin{array}{c}1.44 \\
(0.71-2.89)\end{array}$ & & $76(65.0)$ & 0.65 & $\begin{array}{c}0.74 \\
(0.36-1.53)\end{array}$ & \\
\hline No & $16(32.7)$ & & 1.0 & & $35(71.4)$ & & 1.0 & \\
\hline \multicolumn{9}{|l|}{ Medical treatment (1 missing) } \\
\hline Yes & $12(27.3)$ & 3.35 & $\begin{array}{c}0.50 \\
(0.23-1.06)\end{array}$ & $\begin{array}{c}0.47 \\
(0.21-1.05)\end{array}$ & $23(52.3)$ & 6.13 & $\begin{array}{c}0.41 \\
(0.20-0.84)^{*}\end{array}$ & $\begin{array}{c}0.39 \\
(0.14-1.07)\end{array}$ \\
\hline No & $52(43.0)$ & & 1.0 & 1.0 & $88(72.7)$ & & 1.0 & 1.0 \\
\hline \multicolumn{9}{|l|}{ Drinking (3 missing) } \\
\hline Yes & $27(39.1)$ & 0.00 & $\begin{array}{c}0.99 \\
(0.52-1.87)\end{array}$ & & $45(65.2)$ & 0.15 & $\begin{array}{c}0.88 \\
(0.46-1.70)\end{array}$ & \\
\hline No & $37(39.4)$ & & 1.0 & & $64(68.1)$ & & 1.0 & \\
\hline \multicolumn{9}{|l|}{ Age started smoking } \\
\hline $\begin{array}{l}\text { Childhood / adolescence } \\
\text { (< } 19 \text { years) }\end{array}$ & $54(40.6)$ & 1.18 & $\begin{array}{c}1.57 \\
(0.69-3.57)\end{array}$ & & $90(67.7)$ & 0.19 & $\begin{array}{c}1.20 \\
(0.54-2.65)\end{array}$ & \\
\hline Adulthood ( $\geq 19$ years) & $10(30.3)$ & & 1.0 & & $21(63.6)$ & & 1.0 & \\
\hline
\end{tabular}




\begin{tabular}{|c|c|c|c|c|c|c|c|c|}
\hline \multicolumn{9}{|l|}{ Daily cigarette consumption } \\
\hline$\leq 20$ & $37(33.9)$ & 2.85 & $\begin{array}{c}0.57 \\
(0.30-1.10)\end{array}$ & $\begin{array}{c}0,46 \\
(0,22-0,92)^{*}\end{array}$ & $68(62.4)$ & 2.88 & $\begin{array}{c}0.54 \\
(0.26-1.11)\end{array}$ & $\begin{array}{c}0.57 \\
(0.20-1.63)\end{array}$ \\
\hline$>20$ & $27(47.4)$ & & 1.0 & 1.0 & $43(75.4)$ & & 1.0 & 1.0 \\
\hline \multicolumn{9}{|l|}{$\begin{array}{l}\text { Previous attempt to quit ( } 3 \\
\text { missing) }\end{array}$} \\
\hline No & $10(30.3)$ & 1.22 & $\begin{array}{c}0.63 \\
(0.28-1.44)\end{array}$ & & $19(57.6)$ & 1.85 & $\begin{array}{c}0.58 \\
(0.27-1.28)\end{array}$ & \\
\hline Yes & $53(40.8)$ & & 1.0 & & $91(70.0)$ & & 1.0 & \\
\hline \multicolumn{9}{|l|}{$\begin{array}{l}\text { Tobacco dependence - NHSDA } \\
\text { (37 missing) }\end{array}$} \\
\hline Yes & $50(44.6)$ & 0.41 & $\begin{array}{c}0.72 \\
(0.26-1.99)\end{array}$ & & $80(71.4)$ & 0.89 & $\begin{array}{c}0.54 \\
(0.14-1.99)\end{array}$ & \\
\hline No & 9 (52.9) & & 1.0 & & $14(82.4)$ & & 1.0 & \\
\hline \multicolumn{9}{|l|}{ FTND (1 missing) } \\
\hline $\begin{array}{l}\geq 5 \text { (moderate to very } \\
\text { heavy) }\end{array}$ & $37(36.6)$ & 0.26 & $\begin{array}{c}0.85 \\
(0.44-1.61)\end{array}$ & & $72(71.3)$ & 2.50 & $\begin{array}{c}1.70 \\
(0.88-3.28)\end{array}$ & $\begin{array}{c}0.97 \\
(0.34-2.78)\end{array}$ \\
\hline$<5$ (very light to light) & $26(40.6)$ & & 1.0 & & $38(59.4)$ & & 1.0 & 1.0 \\
\hline \multicolumn{9}{|l|}{$\begin{array}{l}\text { Contemplation ladder } \\
(2 \text { missing) }\end{array}$} \\
\hline $\begin{array}{l}\text { Precontemplation/ } \\
\text { contemplation }\end{array}$ & $10(34.5)$ & 0.17 & $\begin{array}{c}0.84 \\
(0.36-1.95)\end{array}$ & & $21(72.4)$ & 0.56 & $\begin{array}{c}1.40 \\
(0.58-3.41)\end{array}$ & \\
\hline Preparation/action & $52(38.5)$ & & 1.0 & & $88(65.2)$ & & 1.0 & \\
\hline \multicolumn{9}{|l|}{ URICA (2 missing) } \\
\hline Low motivation & $35(40.7)$ & 0.40 & $\begin{array}{c}1.23 \\
(0.65-2.31)\end{array}$ & & $58(67.4)$ & 0.08 & $\begin{array}{c}1.10 \\
(0.57-2.10)\end{array}$ & \\
\hline High motivation & $28(35.9)$ & & 1.0 & & $51(65.4)$ & & 1.0 & \\
\hline \multicolumn{9}{|l|}{$\begin{array}{l}\text { Symptoms of depression - BDI } \\
\text { ( } 7 \text { missing) }\end{array}$} \\
\hline Mild/moderate/severe $(>11)$ & $30(36.6)$ & 0.02 & $\begin{array}{c}0.96 \\
(0.50-1.82)\end{array}$ & & $57(69.5)$ & 1.26 & $\begin{array}{c}1.46 \\
(0.76-2.81)\end{array}$ & \\
\hline Minimal $(\leq 11)$ & $29(37.7)$ & & 1.0 & & $47(61.0)$ & & 1.0 & \\
\hline \multicolumn{9}{|l|}{$\begin{array}{l}\text { Symptoms of anxiety - BAI ( } 4 \\
\text { missing) }\end{array}$} \\
\hline Mild/moderate/severe $(>10)$ & $35(40.2)$ & 0.14 & $\begin{array}{c}1.13 \\
(0.60-2.13)\end{array}$ & & $65(74.7)$ & 5.47 & $\begin{array}{c}2.20 \\
(1.13-4.28)^{*}\end{array}$ & $\begin{array}{c}3.07 \\
(1.25-7.56)^{*}\end{array}$ \\
\hline Minimal $(\leq 10)$ & $28(37.3)$ & & 1.0 & & $43(57.3)$ & & 1.0 & 1.0 \\
\hline
\end{tabular}

95\% CI = 95\% confidence interval; BAI = Beck Anxiety Inventory; BDI = Beck Depression Inventory; FTND = Fagerström Test for Nicotine Dependence; NHSDA = National Household Survey on Drug Abuse; URICA = University of Rhode Island Change Assessment Scale. Multivariate analysis: adjusted for gender, age, household income, medical treatment, number of cigarettes, FTND, and BAI. $* p<0.05$.

For final adherence, older age was associated with higher adherence $(p=0.001)$ and not being on medical treatment for hypertension, diabetes, or other chronic diseases decreased the likelihood of adherence ( $p=$ 0.015 ). Moreover, minimal anxiety symptoms increased the likelihood that smokers would attend the meetings ( $p=$ 0.02 ). Household income, daily cigarette consumption and FTND score yielded a trend in associations $(p<0.2)$ and therefore these predictors were included in a multivariate logistic regression analysis. The association between adherence and anxiety symptoms was confirmed after adjusting the results for attendance at the fourth session by logistic regression ( $p=0.014$ ) (Table 2 ).

Regardless of the session, smokers who were on medical treatment for clinical conditions tended to attend more group sessions $(p=0.061$ for immediate and $p=$ 0.067 for final adherence).

\section{Discussion}

This study sought to distinguish characteristics that interfere with participation in a smoking cessation program at two different times: the first return (second session) and the end of the support program for smoking cessation (fourth session). The results indicated that older adult smokers, those smoking fewer cigarettes per day, and those with a minimal level of anxiety symptoms were more likely to adhere to treatment, at different points during the program. Smokers who were on medical treatment for clinical conditions likely to be associated with smoking tended to attend more group sessions.

The profile of the smokers who participated in the support group suggested that adherence to treatment may be most common among older people who have smoked for longer periods. This finding is consistent 
with prior studies about smoking cessation. ${ }^{23,45-47}$ Further research is needed to develop strategies and approaches that attract younger adult smokers and increase their adherence to treatment. The demand for specialized treatment as well as managing to reach the stage of attempting to quit smoking among younger people $e^{48,49}$ should be valued because stopping smoking before the onset of smoking-related illness represents a gain in health for both the individual and for society.

It is generally assumed that heavy smokers would be more likely to seek expert care and to engage with it, $25,45,46,50$ because they recognize the level of difficulty they would face if they attempted to achieve abstinence by their own efforts. ${ }^{47,51}$ However, in the current study, the less the participants smoked the more likely they were to attend group sessions. Similarly, Asfar et al. ${ }^{18}$ reported a trend towards an association between lower numbers of cigarettes smoked and greater adherence to face-to-face treatment. The lack of autonomy over smoking, that even smokers with low-rate consumption may develop, ${ }^{52}$ may explain why cessation is difficult in this group and why they also seek and engage with specialized treatment.

Anxiety is a symptom that is commonly observed in tobacco withdrawal syndrome $\mathrm{e}^{53}$ and is considered a predictor of relapse. ${ }^{54-56}$ The association between anxiety and adherence to treatment for smoking cessation has not been studied extensively, and our report has demonstrated that smokers with lower levels of anxiety showed higher final adherence to the program. Likewise, Kuhl et al. ${ }^{57}$ concluded that anxiety was a predictor of poor adherence to smoking treatment in postmyocardial infarction patients. It may be the case that anxious smokers do not benefit fully from the group sessions because they may request special attention from the professional who leads the groups during the discussions. Furthermore, quitting smoking represents the loss of a control or of a coping mechanism for their anxiety and, for this reason, smokers with high levels of anxiety feel less able to stop due to increased symptoms of withdrawal. ${ }^{54,58}$ However, symptoms of anxiety did not influence the probability of maintaining abstinence among smokers attending individualized pharmacological therapy. ${ }^{59}$ In another study, anxiety was only a predictor of failure to achieve abstinence among women. ${ }^{60}$

Interestingly, different characteristics were associated with adherence at the two points during the program that were studied. From a theoretical point of view, adherence can be intentional or unintentional ${ }^{11,24}$ and it seems that age and number of cigarettes are associated with the intention and decision to abandon the treatment, while the symptoms of anxiety are negative and unintentionally discourage smokers from trying to quit smoking until they eventually drop out of treatment. ${ }^{61}$

Reporting a tobacco-related disease did not alter the probability of compliance with the treatment program at either point in the program. This result is in contrast to findings reported by Klesges et al., ${ }^{14}$ who observed that smokers with high perceived vulnerability to tobaccorelated diseases were more likely to enter a treatment program. Smokers who were not receiving medical treatment for a chronic disease tended to adhere less to the support group, suggesting that adherence to one medical treatment may influence adherence to subsequent health care. This finding supports the idea that adherence may be understood as a unitary pattern in which events related to health would motivate a person to adopt spontaneous care for other behaviors. ${ }^{62,63}$

These results might indicate that women tend to worry more about health and are more likely to seek and retain expert care. ${ }^{23,47,64,65}$ Adherence was not associated with the sociodemographic characteristics marital status, educational level, occupation, or household income, confirming some studies of the relationship between these characteristics and seeking or adhering to treatment ${ }^{18,46}$ but contrasting with others. ${ }^{25,66}$ In other studies, women, ${ }^{23,46,66}$ older individuals, ${ }^{23,25,46}$ people who were not employed, ${ }^{23,66}$ and those with higher educational levels ${ }^{23}$ were more likely to adhere to treatment.

The prevalence of depression is higher among smokers ${ }^{67,68}$ and studies concerning the relationship between depression and adherence to a cognitivebehavioral therapy group for smoking cessation have shown contradictory results. ${ }^{16,25,26}$ Our results revealed no association between level of depressive symptoms and adherence to treatment. However, other studies have shown that depressive symptoms serve as predictors of achievement of abstinence and relapse, ${ }^{67,69,70}$ likely because smokers who are more depressed may have fewer coping skills and greater dependence on the mood-enhancing effects of nicotine than smokers who are not depressed. ${ }^{71}$

Adherence to treatment reflects an individual's level of motivation and may be influenced by their beliefs about and attitudes toward treatment and the level of their desire to quit smoking. ${ }^{13,72,73}$ Commonly, a strong intention to quit smoking is seen as a state of high motivation and is considered to be a powerful predictor of adherence to treatment. ${ }^{45,51,50}$ Moreover, low motivation may be an individual-level barrier leading to treatment default. ${ }^{74}$ Unlike what might be expected based on previous literature, smokers in this study equally attended the program in the two periods investigated regardless of their degree of motivation to quit smoking. Further studies should be planned to 
investigate the influence of smokers' expectations on the efficacy of their attempts to quit.

It is known that group-based behavioral interventions are more effective than self-help materials, advice, or no intervention. ${ }^{4,75,76}$ Furthermore, group treatments have similar efficacy and effectiveness to individual interventions for smoking cessation treatment.4,17 However, despite the recognized efficacy of this approach, adherence to group programs remains a barrier to tobacco control; no more than 40 to $60 \%$ of the smokers who begin these treatments attend the meetings consistently, $23 \%$ of the participants leave treatment within the first month, and around $45 \%$ leave it within two months. ${ }^{16,17}$ In our study, adherence to the support group was even lower, with only one-third of the individuals attending all the meetings in one month. Poor adherence is also a problem in group treatment of other addictions; for example, only around $20 \%$ of alcoholics in Brazil are still attending Alcoholics Anonymous meetings at six-month follow-up. ${ }^{77}$

Comparing the approach used here with studies from other countries may prove disappointing, mainly due to intrinsic characteristics of the support groups in Brazil. Usually these treatments are provided by public health services ${ }^{5}$ and recruitment is carried out reactively. Moreover, patients' participation is not accompanied by any kind of incentive, principally financial incentives. Therefore, the adherence rate to treatment solely reflects the individual patient's commitment to and engagement with the proposed scheme per se and, not surprisingly, is lower than rates found in international studies.

Despite the objective contained in Brazil's National Tobacco Control Plan to increase smokers' access to effective methods of smoking cessation, efforts are still insufficient: only $6.7 \%$ of smokers have tried to quit using pharmacotherapy, for example. ${ }^{2}$ Since support groups are a central approach to smoking cessation in Brazil, it is important to know the predictors of adherence to support groups to be able to plan this treatment better. Health professionals who deliver these interventions should be able to identify smokers at higher risk of nonengagement, even if they show interest in following the activities proposed in a first contact. Even smokers who adhere poorly to the support group may benefit from other strategies to increase their engagement with this treatment before referring them to drug treatment.

These people should receive special attention phone calls, mobile phone messages, letters, and e-mails to remind them of upcoming meetings could help to improve attendance rates. It may also be possible to increase adherence to support groups by using initial sessions to administer motivational interventions designed to increase smokers' engagement with the group therapy. ${ }^{21}$ These individual sessions could also serve as screening interviews to avoid prescribing group treatment for people who will not adapt to this approach. Biofeedback can also be an interesting strategy. Adding a clinical or biological marker of the consequences of tobacco use to group discussions could more strongly motivate smokers to seek to change this situation. This would add a measurable index to the subjective benefits of following the treatment.

Practitioners interested in maximizing adherence could consider providing this treatment to specific groups of smokers. It is probable that adaptations to interventions are needed for less adherent smokers and possibly a proposal for group therapy with only these smokers should be considered. Moreover, it is also possible that these smokers need different approaches simultaneously.

The current study should be interpreted with some degree of caution. The sample was non-probabilistic and the subjects were enrolled in a clinical setting and therefore may not be representative of all smokers. The sample size was calculated based on an adherence rate that was higher than the rate actually observed in this study and so some of the results may not have been significant because of small sample size. Moreover, some participants who were lost to follow up may have stopped smoking and so not have perceived any utility in attending subsequent support group meetings. To the extent that this occurred, the findings may be biased toward understanding factors related to adherence among program participants who experience a negative program outcome (i.e., failure to achieve abstinence). The lack of contact with dropouts is one limitation to this study. More conclusive results would be possible with a larger group of participants and a systematic investigation of the reasons individuals did not continue to attend the meetings.

\section{Conclusion}

Determination of predictors of adherence to programs for smoking cessation might provide scientific knowledge that could then be used to develop treatments tailored to improve the adherence of smokers and, consequently, the outcomes of interventions. Our results showed that older smokers and smokers who smoked fewer cigarettes per day had higher immediate adherence to the treatment and that smokers with lower levels of anxiety had higher final adherence to the treatment. One would imagine that these smokers have fewer complicating factors and so could achieve success with support groups alone. Since there is a lack of access to pharmacotherapy in low 
resource situations, studying the performance of these smokers is a subject for further research.

\section{Acknowledgements}

The authors are grateful to psychologists Andreia Engel, Cláudia G. Mazoni, Cassandra B. Bortolon, Mariana C. Benchaya, and Nadia K. Bisch, who conducted the sessions of support group for smoking cessation.

\section{References}

1. Instituto Brasileiro de Geografia e Estatística (IBGE). Pesquisa Nacional de Saúde 2013 - Percepção do estado de saúde, estilos de vida e doenças crônicas: Brasil, Grandes Regiões e Unidades da Federação [Internet]. 2014 [cited 2016 Nov 21]. ftp://ftp.ibge. gov.br/PNS/2013/pns2013.pdf

2. Instituto Nacional do Câncer (INCA). A situação do tabagismo no Brasil: dados dos inquéritos do Sistema Internacional de Vigilância, da Organização Mundial da Saúde, realizados no Brasil, entre 2002 e 2009 [Internet]. 2011 [cited 2016 Nov 21]. http://www1.inca. gov.br/inca/Arquivos/situacao tabagismo.pdf

3. Chapman S, MacKenzie R. The global research neglect of unassisted smoking cessation: causes and consequences. PLoS Med. 2010;7:e1000216.

4. Stead LF, Lancaster T. Group behaviour therapy programmes for smoking cessation. Cochrane Database Syst Rev. 2005; (2):CD001007.

5. Brasil, Ministério da Saúde (MS). Plano para implantação da abordagem e tratamento do tabagismo no SUS e Protocolo Clínico e Diretrizes Terapêuticas - Dependência à Nicotina. Brasília. Diário Oficial da União. 2013. [cited 2016 Jun 03]. bvsms.saude.gov.br/ bvs/saudelegis/gm/2013/prt0571_05_04_2013.html

6. Wright EC. Non-compliance - or how many aunts has Matilda? Lancet. 1993;342:909-13.

7. Horwitz RI, Horwitz SM. Adherence to treatment and health outcomes. Arch Intern Med. 1993;153:1863-8.

8. Dunbar-Jacob J, Mortimer-Stephens MK. Treatment adherence in chronic disease. J Clin Epidemiol. 2001;54:S57-60.

9. van Dulmen S, Sluijs E, van Dijk L, de Ridder D, Heerdink R, Bensing J. Patient adherence to medical treatment: a review of reviews. BMC Health Serv Res. 2007; 7:55.

10. Clinical Practice Guideline Treating Tobacco Use and Dependence 2008 Update Panel, Liaisons, and Staff. A clinical practice guideline for treating tobacco use and dependence: 2008 update. A U.S. Public Health Service report. Am J Prev Med. 2008;35:158-76.

11. Vermeire $E$, Hearnshaw $H$, Van Royen $P$, Denekens J. Patient adherence to treatment: three decades of research. A comprehensive review. J Clin Pharm Ther. 2001;26:331-42.

12. Patterson $F$, Jepson $C$, Kaufmann V, Rukstalis M, Audrain-McGovern J, Kucharski S, et al. Predictors of attendance in a randomized clinical trial of nicotine replacement therapy with behavioral counseling. Drug Alcohol Depend. 2003;72:123-31.

13. Fucito LM, Toll BA, Salovey P, O'Malley SS. Beliefs and attitudes about bupropion: implications for medication adherence and smoking cessation treatment. Psychol Addict Behav. 2009;23:373-9.

14. Klesges RC, Brown K, Pascale RW, Murphy M, Williams E, Cigrang JA. Factors associated with participation, attrition, and outcome in a smoking cessation program at the workplace. Health Psychol. 1988:7:575-89.

15. Rosenbaum $P, O^{\prime}$ Shea R. Large-scale study of freedom from smoking clinics- factors in quitting. Public Health Rep. 1992;107:150-5.

16. Curtin L, Brown RA, Sales SD. Determinants of attrition from cessation treatment in smokers with a history of major depressive disorder. Psychol Addict Behav. 2000;14:134-42.

17. Camarelles F, Asensio Á, Jiménez-Ruiz C, Becerril B, Rodero $D$ Vidaller O. [Effectiveness of a group therapy intervention to quit smoking. Randomized clinical trial]. Med Clin (Barc). 2002;119:53-7.

18. Asfar T, Weg MV, Maziak W, Hammal F, Eissenberg T, Ward KD. Outcomes and adherence in Syria's first smoking cessation trial. Am J Health Behav. 2008:32:146-56.
19. Paul CL, McLennan J, Baxendale A, Schnelle B, Rawson J, Turon

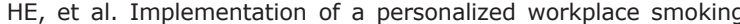
cessation programme. Occup Med (Lond). 2013;63:568-74.

20. Sales MP, de Figueiredo MR, de Oliveira MI, de Castro HN. Outpatient smoking cessation program in the state of Ceará, Brazil: patient profiles and factors associated with treatment success. J Bras Pneumol. 2006;32:410-7.

21. Azevedo RC, Fernandes RF. Factors relating to failure to quit smoking: a prospective cohort study. Sao Paulo Med J. 2011;129:380-6.

22. Mesquita AA. Avaliação de um programa de tratamento do tabagismo. Rev Bras Ter Comp Cogn. 2013;15:35-44.

23. Pawlina MM, Rondina RC, Espinosa MM, Botelho C. Abandonment of nicotine dependence treatment: a cohort study. Sao Paulo Med J. 2016;134:47-55.

24. Reach $G$. Role of habit in adherence to medical treatment. Diabet Med. 2005;22:415-20.

25. Ginsberg JP, Klesges RC, Johnson KC, Eck LH, Meyers AW, Winders $\mathrm{SA}$. The relation between a history of depression and adherence to a multicomponent smoking-cessation program. Addict Behav. 1997;22:783-7

26. Patten CA, Drews AA, Myers MG, Martin JE, Wolter TD. Effect of depressive symptoms on smoking abstinence and treatment adherence among smokers with a history of alcohol dependence. Psychol Addict Behav. 2002;16:135-42.

27. Ben Taleb Z, Ward KD, Asfar $T$, Jaber $R$, Auf $R$, Maziak W. Predictors of nicotine withdrawal symptoms: findings from the first randomized smoking cessation trial in a low-income country setting. Int J Public Health. 2016;61:701-8.

28. Wing $R R$, Phelan $S$, Tate $D$. The role of adherence in mediating the relationship between depression and health outcomes. J Psychosom Res. 2002;53:877-81.

29. Miller WR, Rollnick S. Motivational interviewing: helping people change. New York: Guilford; 2013.

30. American Cancer Society. Freshstart: American Cancer Society; 1996.

31. Brasil, Ministério da Saúde, Secretaria de Atenção à Saúde, Instituto Nacional do Câncer (INCA), Coordenação de Prevenção e Vigilância. Deixando de fumar sem mistérios. $2^{a}$ ed. Rio de Janeiro: INCA; 2004.

32. DiClemente CC, Prochaska JO. Self-change and therapy change of smoking behavior: a comparison of processes of change in cessation and maintenance. Addict Behav. 1982;7:133-42.

33. Carlini EA, Galduróz JCF, Noto AR. II Psychotropic drug use in Brazil: a household survey in the 108 largest cities of the country - 2005. Brasília: Secretaria Nacional Antidrogas; 2007.

34. Center for Behavioral Health Statistics and Quality (CBHSQ), Substance Abuse and Mental Health Services Administration (SAMHSA), U.S. Department of Health and Human Services (HHS), RTI International. Results from the 2013 national survey on drug use and health: detailed tables [Internet]. 2013 [cited 2016 Jan 16]. samhsa.gov/data/sites/default/files/NSDUH-DetTabs2013/ NSDUH-DetTabs2013.htm\#toc

35. Fagerström KO. Measuring degree of physical dependence to tobacco smoking with reference to individualization of treatment. Addict Behav. 1978;3:235-41.

36. Carmo JT, Pueyo AA. A adaptação do português do Fagesrtröm test for nicotine dependence (FTND) para avaliar a dependência e tolerância à nicotina em fumantes brasileiros. Rev Bras Med. 2002;58:73-80.

37. McConnaughy E A, Prochaska JO, Velicer WF. Stages of change in psychotherapy: measurement and sample profiles. Psychother Theor Res Pract. 1983;20:368-75.

38. Biener L, Abrams DB. The Contemplation Ladder: validation of a measure of readiness to consider smoking cessation. Health Psychol. 1991;10:360-5.

39. Terra MB, Silveira DX, Moreira TC, Ferigolo M, Mazoni C, Arena FX, et al. Convergent validation study of the Contemplation Ladder for application via telephone in tobacco users. J Bras Psiquiatr. 2009,58:143-9.

40. Prochaska JO, Diclemente C. Trans theoretical therapy: toward a more integrative model of change. Psychother Theor Res Pract. 1982;19:276-88.

41. Beck AT, Epstein N, Brown G, Steer RA. An inventory for measuring clinical anxiety: psychometric properties. J Consult Clin Psychol. 1988;56:893-7

42. Cunha JA. Manual da versão em português das escalas Beck. São Paulo: Casa do Psicólogo; 2011.

43. Beck AT, Ward $\mathrm{CH}$, Mendelson M, Mock J, Erbaugh J. An inventory for measuring depression. Arch Gen Psychiatry. 1961;4:561-71. 
44. Hughes JR, Keely J, Naud S. Shape of the relapse curve and long-term abstinence among untreated smokers. Addiction. 2004;99:29-38.

45. Hennrikus DJ, Jeffery RW, Lando HA. The smoking cessation process: longitudinal observations in a working population. Prev Med. 1995;24:235-44.

46. Zhu S, Melcer T, Sun J, Rosbrook B, Pierce JP. Smoking cessation with and without assistance: a population-based analysis. Am J Prev Med. 2000;18:305-11.

47. Shiffman S, Brockwell SE, Pillitteri JL, Gitchell JG. Individual differences in adoption of treatment for smoking cessation: demographic and smoking history characteristics. Drug Alcohol Depend. 2008;93:121-31.

48. Levy DT, Romano E, Mumford E. The relationship of smoking cessation to sociodemographic characteristics, smoking intensity, and tobacco control policies. Nicotine Tob Res. 2005;7:387-96.

49. Hughes JR, Cohen B, Callas PW. Treatment seeking for smoking cessation among young adults. J Subst Abuse Treat. 2009;37:2113.

50. Thompson B, Rich LE, Lynn WR, Shields R, Corle DK. A voluntary smokers' registry: characteristics of joiners and non-joiners in the Community Intervention Trial for Smoking Cessation (COMMIT). Am J Public Health. 1998;88:100-3.

51. Pohl JM, Martinelli A, Antonakos C. Predictors of participation in a smoking cessation intervention group among low-income women. Addict Behav. 1998;23:699-704.

52. Wellman RJ, DiFranza JR, Wood C. Tobacco chippers report diminished autonomy over smoking. Addict Behav. 2006;31:71721.

53. Mykletun A, Overland S, Aarø LE, Liabø HM, Stewart R. Smoking in relation to anxiety and depression: evidence from a large population survey: the HUNT study. Eur Psychiatry. 2008;23:7784

54. Morrell HE, Cohen LM, al'Absi M. Physiological and psychological symptoms and predictors in early nicotine withdrawal. Pharmacol Biochem Behav. 2008;89:272-8.

55. Park ER, Chang Y, Quinn V, Regan S, Cohen L, Viguera A, et al. The association of depressive, anxiety, and stress symptoms and postpartum relapse to smoking: a longitudinal study. Nicotine Tob Res. 2009;11:707-14.

56. Irfan M, Haque AS, Shahzad H, Samani ZA, Awan S, Khan JA. Reasons for failure to quit: a cross-sectional survey of tobacco use in major cities in Pakistan. Int J Tuberc Lung Dis. 2016;20:673-8.

57. Kuhl EA, Fauerbach JA, Bush DE, Ziegelstein RC. Relation of anxiety and adherence to risk-reducing recommendations following myocardial infarction. Am J Cardiol. 2009;103:1629-34.

58. Weinberger AH, Desai RA, McKee SA. Nicotine withdrawal in U.S. smokers with current mood, anxiety, alcohol use, and substance use disorders. Drug Alcohol Depend. 2010;108:7-12.

59. Cosci F, Bertoli G, Pistelli F, Carrozzi L. Depressive, anxious, withdrawal symptoms, and craving as possible predictors of abstinence maintenance in smokers attending a 12-week quitting program [Internet]. MedicalExpress (São Paulo, online). 2016;3 [cited 2016 Dec 19]. http://dx.doi.org/10.5935/ MedicalExpress.2016.01.03

60. Marqueta A, Nerín I, Jiménez-Muro A, Gargallo P, Beamonte A. [Predictors of outcome of a smoking cessation treatment by gender]. Gac Sanit. 2013;27:26-31.

61. Jesus MC, Silva MH, Cordeiro SM, Kortchmar E, Zampier VS, Merighi MA. [Understanding unsuccessful attempts to quit smoking: a social phenomenology approach]. Rev Esc Enferm USP. 2016;50:73-80.

62. McBride CM, Emmons KM, Lipkus IM. Understanding the potential of teachable moments: the case of smoking cessation. Health Educ Res. 2003;18:156-70.

63. Persky I, Spring B, Vander Wal JS, Pagoto S, Hedeker D. Adherence across behavioral domains in treatment promoting smoking cessation plus weight control. Health Psychol. 2005;24:153-60.

64. Santos SR, Gonçalves MS, Leitão Filho FS, Jardim JR. Profile of smokers seeking a smoking cessation program. J Bras Pneumol. 2008;34:695-701.

65. Szklo AS, Otero UB. [Profile of smokers not searching for smoking cessation intervention in Rio de Janeiro, Brazil]. Rev Saude Publica. 2008;42:139-42.

66. Kviz FJ, Crittenden KS, Warnecke RB. Factors associated with nonparticipation among registrants for a self-help, communitybased smoking cessation intervention. Addict Behav. 1992;17:53342.

67. Covey LS, Glassman AH, Stetner F. Depression and depressive symptoms in smoking cessation. Compr Psychiatry. 1990;31:3504.

68. Ong AD, Walsh DA. Nicotine dependence, depression, and the moderating role of goal cognitions. Psychol Addict Behav. 2001;15:252-4.

69. Niaura R, Britt DM, Shadel WG, Goldstein M, Abrams D, Brown R. Symptoms of depression and survival experience among three samples of smokers trying to quit. Psychol Addict Behav. 2001; 15:13-7.

70. Kronish IM, Rieckmann N, Halm EA, Shimbo D, Vorchheimer $D$, Haas DC, et al. Persistent depression affects adherence to secondary prevention behaviors after acute coronary syndromes. J Gen Intern Med. 2006;21:1178-83.

71. Hitsman B, Abrams DB, Shadel WG, Niaura R, Borrelli B, Emmons $\mathrm{KM}$, et al. Depressive symptoms and readiness to quit smoking among cigarette smokers in outpatient alcohol treatment. Psychol Addict Behav. 2002;16:264-8.

72. Van Der Rijt GA, Westerik $H$. Social and cognitive factors contributing to the intention to undergo a smoking cessation treatment. Addict Behav. 2004;29:191-8.

73. Piette JD, Heisler M, Ganoczy D, McCarthy JF, Valenstein M. Differential medication adherence among patients with schizophrenia and comorbid diabetes and hypertension. Psychiatr Serv. 2007;58:207-12.

74. Lee ML, Hassali MA, Shafie AA. A qualitative exploration of the reasons for the discontinuation of smoking cessation treatment among Quit Smoking Clinics' defaulters and health care providers in Malaysia. Res Social Adm Pharm. 2013;9:405-18.

75. Bala MM, Lesniak W. Efficacy of non-pharmacological methods used for treating tobacco dependence: meta-analysis. Pol Arch Med Wewn. 2007;117:504-11.

76. Mottillo S, Filion KB, Bélisle P, Joseph L, Gervais A, O'Loughlin J, et al. Behavioural interventions for smoking cessation: a meta-analysis of randomized controlled trials. Eur Heart J. 2009;30:718-30.

77. Terra MB, Barros HM, Stein AT, Figueira I, Palermo LH, Athayde LD, et al. Do alcoholics anonymous groups really work? Factors of adherence in a Brazilian sample of hospitalized alcohol dependents. Am J Addict. 2008;17:48-53.

\section{Correspondence:}

Luciana Rizzieri Figueiró

Universidade Federal de Ciências da Saúde de Porto Alegre (UFCSPA)

Rua Sarmento Leite, 245/316

90050-170 - Porto Alegre, RS - Brazil

Tel./Fax: +55-51-3303-8764

E-mail: rizzieri@ufcspa.edu.br 